\title{
PAPALELE \\ (SUATU TINJAUAN HISTORIS TERHADAP BUDAYA MASYARAKAT AMBON)
}

\author{
EFILINA KISSIYA \\ Fakultas Keguruan dan Ilmu Pendidikan, Universitas Pattimura Ambon
}

\begin{abstract}
Abstrak
Papalele merupakan suatu kegiatan berjualan yang sudah ada sejak dulu pada masyarakat Ambon. Papalele biasanya dilakukan oleh ibu-ibu dengan pakaian mereka yang khas (oleh orang-orang Ambon umumnya menyebut mereka dengan sebutan Tanta-tanta papalele. Kegiatan mereka biasanya dimulai pada waktu subuh mereka sudah berjalan kaki tanpa menggunakan alas kaki dari tempat tinggal mereka ke pusat kota Ambon. Tidak diketahui persis kapan dan siapa yang memulai kegiatan ini pada awalnya, tetapi yang pasti kegiatan Papalele ini sudah ada sejak dulu dalam bentuk menjajakan dagangan secara berkeliling dari rumah ke rumah, atau dengan cara duduk di pinggir jalan. Mereka yang menjual secara berkeliling meletakan jualannya di atas dulang (wadah berbentuk bulat yang terbuat dari kayu) diletakkan di atas kepala (Keku). Seiring dengan berlalunya waktu, Papalele ini mulai berkembang ke arah berjualan yang sifatnya tetap di pasar (dudu pasar). Pada saat ekonomi kapitalis merambah dunia dengan berbagai tawaran yang menyenangkan dan menggiurkan, kegiatan Papalele masih tetap eksis dengan cara penawaran tradisional, mampu bersaing dalam perekonomian modern. Ini dilakukan untuk bagaimana menghidupi keluarga dan masa depan keluarga mereka. Eksistensinya itu diwujudkan dalam bentuk melayani masyarakat untuk memenuhi kebutuhan kesehariannya. Oleh sebab itu, Papalele juga mampu menciptakan pasar sendiri, tanpa tergantung pada pasar yang ada. Dan ketika pasar tersegmentasi maka muncul kemudian relasi dan jaringan yang dibangun antar pembeli (konsumen) dan penjual (Pemasok). Jaringan ini dibangun dengan bermodalkan kepercayaan satu sama lain untuk tujuan bersama, dengan harapan tidak saling merugikan.
\end{abstract}

Kata Kunci: papalele, historis, tradisional, berjualan

\section{Pendahuluan}

Dalam kehidupan sehari-hari kita mendapati banyak orangyang melakukan sesuatu untuk mempertahankan dan melanjutkan kehidupannya dalam dunia tindakan, sementara itu tidak sedikit orang yang terus menegaskan kualitas hidupnya, dengan mematut penampilan, memperhalus kata-kata, maupun dengan mengajarkan tidakan-tindakan yang membuat orang yang menaruh perhatian padanya, dan penduduknya di tempat yang 
terpuji. Orang-orang yang melakukan sesuatu hanya untuk mempertahankan dan melanjutkan kehidupan saja dengan tindakan tersebut, dinamakan warga alam. Sedangkan mereka yang mulai menegaskan kualitas hidupnya dengan mematut penampilan, memperhalus kata-kata, maupun dengan mengerjakan tindakan-tindakan yang membuat orang yang menaruh perhatian padanya, itu yang dimaksud dengan warga masyarakat budaya.

\section{Pembahasan}

\section{Arti Papalele?}

Papalele adalah sebutan lokal yang tidak asing lagi bagi masyarakat kota Ambon dan sekitarnya. Mereka adalah orang-orang yang melakukan aktifitas ekonomi jual beli bagi masyarakat. $\mathrm{Pa}$ palele sering menampakan diri dalam aktifitas ekonomi tradisional, khususnya dalam bidang perdagangan yang dijalankan dengan cara membeli suatu barang dan kemudian dijual kembali dengan mendapatkan sedikit keuntungan (Souisa, 1999:39). Papalele jika ditinjau dari etimotologi; terdiri dari dua kata yaitu papa yang artinya membawa atau memikul dan lele yang berarti keliling. Jadi Papalele berarti "berkeliling membawa atau memikul" (Souisa, 1999:38). Paplele juga dapat diartikan sebagai "kegiatan membeli barang, sesudah itu dijual lagi untuk mendapat keuntungan (Mailoa, 2006:75). Papalele sebetulnya dalam keseharian, mereka tidak bedanya sebagai perantara atau (agen) antara konsumen dan produsen (Suegijono:2009:9).

sejarah Papalele dan Papalele sebagai Kearifan Lokal
Konon, Papalele sudah sejak lama ada dan telah dikenal serta di terima oleh masyarakat. Telah asal muasal aktivitas Papalele dalam perkembangannya, sebenarnya di duga mulai ada dan berkembang di kota Ambon dan Maluku sejak asaman VOC yang menekankan sistem hongi. Sebuah modal politik ekonomi untuk melumpuhkan sistem ekonomi masyarakat di kota Ambon pada khusunya.hal ini terkat juga dengan model poloitik'devide et impera'yang di bangun pemerintahan Belanda ketika itu (souisa, 1999:39, Pattikayhatu, 2005:30-38). Kekayaan alam Maluku dari hasil perdagangan pala dan cengkih merupakan bagian dari sistim eksploitasi terjadap sumber daya alam, sehingga model ini adalah cara yang tepat. Kondisi ini terkait dengan kondisi ekonomi secara global yang juga melanda seluruh dunia yang dikenal dengan 'masa resesi ekonomi dunia'pada tahun 1930-an. Politik pemerintahan pada masa gubernur VOC tahun 1576-1934 (dan kemudian Hindia-belanda) menggunakan "politik raad" di pimpin oleh seotang gubernur sejumlah anggota 'oppercoopman fiscal' (kepala urusan keuangan) dan capitein yang menjadi komandan pasukan terhadap beberapa raja-raja karena memiliki hasil bumi yang melimpah dari pala dan cengkih (leiriza et.al,2004:48-60). Politik ini mengatur sistim pemerintahan dan tata niaga cengkih dan pala. Cara ini adalah bentuk untuk mengendalikan penduduk negeri di kota Ambon. sehingga tidak ada kemungkinan peluang masyarakatnya berkembang dari hasil perdagangan. Inilah yang kemudian dirasakan oleh sebagian masyarakat sebagai bentuk konflik vertikal atau bentuk tekanan (hagemoni) ekonomi dari pemerintahan ketika itu terhadap 
aktifitas ekonomoi mereka. Barter secara sembunyi-sembunyi adalah cara untuk mendapatkan kebutuhan lainnya antara sesama penduduk. Diduga dalam kemungkinan perkembangannya, setelah perkembangan ekonomi uang, semakin memperkuat penduduk untuk menjual hasil-hasil pertanian, perkebunan kepada masyarakat yang lebih luas. Model ini lalu kemudian berkembang hingga saat ini dengan sebutan 'papalele'. Papalele dalam aktivitasnya memiliki beberapa pola, hal ini terkait dengan proses menjual suatu barang:

Pola pertama, : Papalele pola ini, biasanya setiap hari akan berkeliling kota, lingkungan pemukiman,dan perkantoran untuk menjumpai pembeli dan pelanggannya. Transaksi ataupun tidak transaksi, tetapi adalah kewajiban Papalele menjumpai konsumen.

Pola kedua, : Papalele, yang menggunakan paruh waktu untuk berkeliling kota dan lingkungan pemukiman (biasanya pagi atau sore), kemudian mengambil posisi tetap pada pasar atau lokasi tertentu menunggu pembeli.

Pola ketiga, : Papalele yang sejak pagi hingga sore hari tetap menempati lokasi tertentu (pasar, depan perkantoran, depan swalayan dII). Pada waktu pulang, mereka akan menggunakan kesempatan berjalan sambil menjual. Biasanya disebut dudu tanding (sebutan bagi orang-orang yang berjualan tetap di pasar, di depan swalayan, perkantoran dll. Tetapi sebutan ini juga biasanya ditujukan bagi orang-orang yang duduk di pinggir jalan, di rumah, tanpa melakukan aktifitas yang berguna. Hanya menunggu waktu makan itulah aktifitas mereka. Seperti tuan dan nyonya).
Papalele adalah tipikal orangorang yang memiliki penghargaan untuk memperbaiki masa depan yang lebih baik bagi anak cucunya. Fromm (2007:13) mengatakan bahwa, mereka adalah yang tidak duduk berpangku tangan, tetapi mengambil langkah dan keputusan yang tepat untuk menghasilkan sesuatu yang bermanfaat. Terkait dengan itu Sutan Takdir Alisjahbana membedakan tiga tingkatan kesadaran manusia dalam menaggapi alam. Partama, menempatkan alam sebagai pendukung kehidupannya, disebut tingkat vital; kedua, memandang alam sebagai penyambung hasratnya, di sebut tanggapan pada tingkat hati; dan yang ketiga, melihat alam sebagai kemungkinan yang dapat dipikirkan, dinamakannya tangggapan pada tingkat akal. Dengan pembedaan itu beliau hendak mengatakan bahwa manusia mempunyai pembawaan dasar, yang sama kuat kecenderungannya, baik kearah pertahanan hidup dan kelangsungan hidup, maupun kearah penegasan kualitas hidup, serta arah penciptaan bentuk-bentuk dan hubungan-hubungan, antara manusia dan dunia yang dihadapinya. Alasanalasan itulah yang mendorong manusia melakukan sesuatu tindakan yang dipilihnya.

Papalele adalah orang-orang yang memiliki motivasi dan kemampuan untuk mengembangkan diri. Pengembangan diri ini terlihat dari berbagai upaya yang dilakukan untuk memperoleh hasil dari proses jual beli. Mereka tidak memiliki ketergantungan pada siapapun dan apapun dalam hidup. Mereka tetap bertahan untuk diri dan keluarga.

Papalele memiliki ciri khusus bagi perempuan menggunakan kain kabaya dengan corak kotak merah dileng- 
kapi dengan perlengkapan dulang (tempat jualan berbentuk bulat yang terbuat dari kayu, biasanya diletakkan di atas kepala), berjalan tanpa menggunakan alas kaki. Sementara laki-laki (Sekarang laki-laki sudah tidak berPapalele lagi. Kegiatan ini dilakukan oleh Perempuan atau ibu-ibu/Tanta-tanta papalele) menggunakan kaos dengan bercelana semi-pendek, dengan perlengkapan hahalang (alat pikul yan terbuat dari kayu/bambu/dahan pohon sagu yang sudah tua umurnya. Untuk dahan sagu biasanya disebut gaba-gaba. Gaba-gaba ini juga digunakan dalam sebuah tarian tradisional Maluku, karena menggunakan gabagaba maka tarian ini dinamakan tari gaba-gaba). Untuk sekarang ini, tidak ada laki-laki yang melakukan kegiatan papalele, umumnya kegiatan ini hanya dilakukan oleh perempuan. Selain itu, Papalele memiliki ciri khusus terhadap barang yang dijual. Hasil perkebunan dan pertanian merupakan produk utama yang di peroleh dari kebun/ pekarangan milik sendiri dan atau dari milik keluarga dan tetangga dilingkungannya. Modal ini yang sering dikenal dengan sistim "dusun/kabong (kebun)". Sistem ini sebetulnya pada awalnya adalah bagian dari upaya masyarakat setempat untuk memenuhi kebutuhan subsidi akan pangan dan kebutuhan lainnya, sehingga pada saat kebutuhan tersebut telah tercukupi, maka diupayakan untuk di barter atau dijual kepada pihak lain (soselissa, 2005:208). Setelah pola ini mengalami perkembangan maka hasilpun akan berada pada kondisi optimal. Jika kemudian hasil perkebunan dan pertanian mengalami kelangkaan karena musim, maka kemudian barang-barang tersebut ambil dari para pedagang yang memasok di kota Ambon.
Para pedagang pemasok ini biasanya dari luar pulau Ambon dan atau dari luar provinsi Maluku. Selain hasil kebun atau pertanian, produk atau bahan yang biasa dijual adalah kue-kue dan ini dibuat sendiri.

Papalele juga memiliki prilaku ekonomi yang rasional yang mempertimbangkan keuntungan dengan tetap mengedepankan nilai-nilai sosial. Sebagaimana Popkins (1979) melihat tentang petani rasional yang tetap memperhitungkan faktor keuntungan dan faktor kerugian dalam beraktivitas. Bagi papalele, sesungguhnya upaya yang dilakukan sangat dipengaruhi oleh nilai-nilai sosial dan budaya. Disisi yang lain, sebagai kegiatan ekonomi skala mikro, memang harus diakui bahwa Papalele sangat lemah dalam mengkases berbagai sumber daya. Kelemahan ini terlihat pada akses input teknologi, keuangan, dan keterampilan (skill). Ketika prilaku ekonomi ini di pengaruhi oleh nilai-nilai sosial dan budaya, maka kemungkinan jusrtu nilai-nilai ini akan lebih diutamakan.

Papalele merupakan sebuah representasi budaya atau tradisi yang berupa kisah-kisah hidup seseorang (personal life narratives), dalam hal ini tanta-tanta Papalele (Perempuan atau ibu-ibu yang melakukan kegiatan papalele) sang tokoh utamanya. Sebagai sebuah representasi, kisah hidup tanta-tanta yang melakukan kegiatan Papalele merupakan salah satu cara untuk membentuk "selfdefinitions" dan identitas (Giles dan Middleton, 1999:55). Apa yang ditampilkan dalam keseharian tanta-tanta Papalele merupakan sebuah realitas yang tergambar dengan jelas di pelupuk mata. 


\section{Papalele, Pengharapan dan Masa Depan}

Masyarakat akan berubah terus sesuai perkembangan jaman dan tidak satupun yang dapat menghambatnya. Nilai-nilai budaya yang dianggap tradisional mungkin akan ditinggalkan dan tentu pula nilai-nilai budaya yang dianggap modern akan menjadi acuan. Memang tidak mudah dalam mempertahankan dan melestarikan sebuah budaya atau sebuah tradisi yang merupakan kearifan lokal. Kapitalisme, globalisasi, dan modernisasi adalah arus gelombang kemajuan duniayang tidak terelakan. Akankah budaya atau tradisi Papalele yang merupakan kearifan lokal masyarakat kota ambon tetap dipertahankan dan dilestraikan? Semua tergantung pada masyarakat pendukung budaya atau tradisi tersebut. Ada masanya suatu tradisi dijunjung dan dimuliakan oleh para pendukung, kemudian pada ketika yang lain, tradisi itu diabaikan. Tradisi yang diabaikan perlu disegarkan kembali. Sekurangkurangnya demikian yang dirasakan oleh sebagian warga yang mengalami beberapa masa kehidupan, pada suatu masa, ia mendapati bahwa bagian-bagian tertentu dari kehidupan masa lalu dikenalnya, kini tidak terlihat lagi hadir ditengah-tengah kehidupan yang dijalaninya. Tidak sedikit tradisi yang hidup dari masa lalu itu yang sekarang terabaikan. Orangpun bertanya, apakah tradisi yang hilang itu pada suatu masa akan menjadi segar kembali? Disisi itu, ada pula tradisi yang sangat terang pengaruhnya pada pola hidup manusia, masa kini karena memang, ia memberikan arti pada peningkatan kualitas hidup manusia yang memerlukarinya. Papalele akan tetap eksis ditengah lajunya mesin dan teknologi yang merambah dunia, jika pendukung-pendukung budaya atau tradisi ini tetap menjalankan dan memelihara dalam keseharian mereka. Atau mungkin saja budaya atau tradisi Papalele ini bisa tergilas habis tak berbekas dimakan oleh lajunya mesin dan teknologi. Dalam ilmu sejarah dan ilmu sosiologi kita kenal dengan apa yang disebut agen perubahan, dalam tulisan ini, saya menyebut tanta-tanta Papalele ini sebagai agen pemertahanan. Dalam arti mereka-mereka inilah yang akan tetap mempertahankan budaya atau tradisi papalele. Karena hanya merekalah yang melakukan kegiatan ini. Tidak semua orang ambon melakukan kegiatan papalele. Kebanyakan yang melakukan kegiatan Papalele ini adalah orang-orang yang tinggal di daerah pegunungan kota Ambon

Kehidupan sehari-hari manusia dipenuhi oleh pengarapan-pengaharapan. Pengharapan-pengharapan itu telah menjadikan banyak perjuangan dilakukan orang, tindakan banyak diputuskan dan kegiatan-kegiatan banyak diselenggarakan. Sama halnya dengan aktor papalele, mereka ingin masa depan yang lebih baik, berlomba-lomba untuk mewujudkan sebuah impian. Dan semua itu tentu saja tidak semudah membalik telapak tangan. Tentu saja dibutuhkan keuletan dan kesungguhan dan kerja keras. Apapun itu semua manusia pasti berusaha untuk memperjuangkan dan mewujudkannya. Tidak orang yang terlalu pintar untuk dengan tidak berusaha. Semuanya itu membutuhkan tindakan yang nyata dan tidak akan terwujud apabila hanya duduk dan merenung tanpa melakukan apa yang dipikirkan. 


\section{Penutup}

Waktu terus bergulir, kebutuhan manusia semakin kompleks, terdesak dengan tuntutan relasi, membuat tanta-tanta Papalele terus berjalan menapaki jalan raya, dengan sejuta harapan bahwa hari esok harus lebih baik dari hari ini.

\section{Daftar Pustaka}

Alisjabana, S, Takcir. 1977. Perkembangan sejarah kebudayaan Indonesia dilihat dari Jurusan Nilai-nilai. Jakarta: loayu Press

Fromm Erich. 2007. Revolusi Pengharapan: Menuju Masyarakat Teknologi yang Semakin Manusiawi. Jakart: Pelongi Cendikia \& PPS IImu Hukum UKK.
Giles, Judi, dan Tim Middeton. 1999. Studying Culture: A Practical introduction. London: Badkwell.

Leiriss, R. Z, dkk. 2004. Ambonku; doeloe, kini, dan esok. Ambon: Pemerintah Kota Ambon.

Maillo, Jan Piet. 2006. Kamus Bahasa-Harian Dialek Orang Ambon. lakarte:Kulibia.

Popkin, S. 1979. The Rational Peasant: The Political Economi Of Rural Society in Vietnam. Bekkeley, University of Callornia Press.

Soseliss, Hermien. 2005. Pengelolaan Lingkungan dalam Budaya Maluku. Dalam Maluku Menyambut Mass Depan.

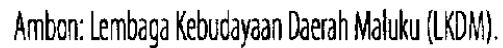

Souisa, Nancy Novitza. 1999. Papalele: Ajang Hidup Berteologi Perempuan Ambon. Saldiga:UKSW (Tesis).

Sugiono, Simon Pieter. 2009. Papalele: Budaya Ekonomi Lokal. Salaiga: UKSW (Tesis). 